DEFAMILIARIZING THE ABORIGINAL:

CULTURAL PRACTICES AND DECOLONIZATION IN CANADA 
This page intentionally left blank 
JULIA V. EMBERLEY

\section{Defamiliarizing the Aboriginal}

Cultural Practices and

Decolonization in Canada

UNIVERSITY OF TORONTO PRESS Toronto Buffalo London 


\section{www.utppublishing.com}

(C) University of Toronto Press Incorporated 2007

Toronto Buffalo London

Printed in Canada

ISBN 978-0-8020-9151-2 (cloth)

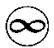

Printed on acid-free paper

\section{Library and Archives Canada Cataloguing in Publication}

Emberley, Julia, 1958-

Defamiliarizing the aboriginal : cultural practices and decolonization in Canada / Julia V. Emberley.

Includes bibliographical references and index.

ISBN 978-0-8020-9151-2

1. Native peoples - Canada-Social conditions - 20th century. 2. Native peoples - Kinship - Social aspects - Canada. 3. Native peoples - Canada Government relations. 4. Family - Canada - History - 20th century.

I. Title.

NX652.I53E42 $2007 \quad 306.85089^{\prime} 97071 \quad$ C2007-902335-5

University of Toronto Press acknowledges the financial assistance to its publishing program of the Canada Council for the Arts and the Ontario Arts Council.

This book has been published with the help of a grant from the Canadian Federation for the Humanities and Social Sciences, through the Aid to Scholarly Publications Programme, using funds provided by the Social Sciences and Humanities Research Council of Canada.

University of Toronto Press acknowledges the financial support for its publishing activities of the Government of Canada through the Book Publishing Industry Development Program (BPIDP). 
To Sophie 
This page intentionally left blank 
The family, as Foucault warns us, should not be seen as a haven from the sexualities of a dangerous outside world, but as the site of their production.

Ann Laura Stoler, Race and the Education of Desire 
This page intentionally left blank 